\title{
High serum levels of IGF-I and IGFBP3 may increase comorbidity risk for asthmatic patients
}

\author{
Acat $\mathrm{M}^{1}$, Toru Erbay $\mathrm{U}^{2}$, Sahin $\mathrm{S}^{3}$, Arik $\mathrm{O}^{4}$, Ayada $\mathrm{C}^{5}$ \\ Department of Physiology, Faculty of Medicine, University of Dumlupinar, Kütahya, Turkey, \\ ceylanayada@gmail.com
}

\section{ABSTRACT}

OBJECTIVE: Asthma is known as a chronic inflammatory lung disease which has also systemic features. Insulin-like growth factor I (IGF-I) plays a role for asthma pathogenesis. Controversially, IGF-binding protein 3 (IGFBP3) blocks asthma development. That is why IGF-I and IGFBP3 are targeted for future therapeutic treatments of asthma. We aimed to investigate serum level of IGF-I and IGFBP3 in patients with asthma. This study was performed in 27 asthma and 23 healthy individuals. Serum levels of IGF-I and IGFBP3 were measured by human ELISA assay kits. Serum levels of IGF-I and IGFBP3 were significanlty higher in the asthma group than the control group. Significant negative correlation was found between IGF-I and asthma control test (ACT) puan, $\mathrm{O}_{2}$ saturation, Forced Expiratory Volume in 1 second/ Forced Vital Capacity (FEV1/FVC), Forced Expiratory Flow 25 second/75 second (FEF2575) (\%). Significant positive correlation was found between IGFBP3 and IGF-I, systolic blood pressure. Significant negative correlation was found between IGF-I and FEV1 (ml). RESULTS: Our results indicate that the serum levels of IGF-I and IGFBP3 are significanlty elevated in the asthma group. We assume that current treatment strategies are not really good enough for asthma. We suppose further strategies which are seeking to balance IGF-I and IGFBP3 should be developed for more effective and curative treatment of asthma (Tab. 2, Fig. 2, Ref. 22). Text in PDF www.elis.sk.

KEY WORDS: insulin-like growth factor I (IGF-I), IGF-binding protein 3 (IGFBP3), asthma.

\section{Introduction}

Synthesis of the insulin-like growth factor I (IGF-I) is induced mainly in the liver by growth hormone $(\mathrm{GH})$ which is secreted under the control of GH-releasing hormone and ghrelin. IGF-I is the major inhibitor of its own secretion and also its secretion is inhibited by somatostatin (Spiess et al, 1983, Kojima et al, 1999, Butler et al, 2001, Brazeau et al, 1973). IGF-I acts as an endocrine factor and plays important role for cell proliferation, differentiation and apoptosis. It interacts with multiple inflammatory mediators. Thus, IGF-I induces subepithelial fibrosis, airway inflammation, hyperresponsiveness and smooth muscle hyperplasia (Lee et al, 2014).

Insulin like growth factor binding proteins (IGFBPs) include six high affinity binding proteins that are responsible for transpor-

${ }^{1}$ Karabük University Faculty of Medicine, Department of Chest Diseases, Karabük, Turkey, ${ }^{2}$ Department of Thoracic Medicine, Faculty of Medicine, University of Dumlupinar, Kütahya, Turkey, ${ }^{3}$ Department of Medical Biology, Faculty of Medicine, University of Dumlupinar, Kütahya, Turkey, ${ }^{4}$ Department of Biostatistic, Faculty of Medicine, University of Dumlupinar, Kütahya, Turkey, and ${ }^{5}$ Department of Physiology, Faculty of Medicine, University of Dumlupinar, Kütahya, Turkey,

Address for correspondence: C. Ayada, Dumlupinar University, Faculty of Medicine Department of Physiology, Merkez Kampüs, Tavşanli Yolu 10. KM, 43100, Kütahya, Turkey.

Phone: +90.505 .6331263 , Fax: +90.274 .2652285$

Acknowledgment: This study was supported by Dumlupinar University Research Fund (Project No: 2013/15). tation of IGF to regulate biological action of IGFs. Most abundant form of IGFBPs is the IGF-binding protein 3 (IGFBP3). It bounds to IGF-I with high affinity and inhibits its effects such as suppression of airway inflammation and airway hyper-responsiveness via IGF-I dependently or independently (Jogie-Brahim et al, 2009, Domené et al, 2005, Yaren et al, 2012).

Asthma is known as a chronic inflammatory lung disease which has systemic features. Airway inflammation, elevated mucus secretion and reversible airway obstruction are considered asthma characteristics (Barnes et al, 2002, Bousquet et al, 2000, Roche et al, 1989).

IGF-I and IGFBP3 are a target for various treatment strategies including allergic airway diseases as well as for the treatment of asthma (Lee et al, 2014). Therefore, we would like to evaluate the effectiveness of current strategies through both of them. For this purpose, we measured serum levels of IGF-I and IGFBP3 in asthma patients who were treated with current therapeutics. We evaluated relationship of clinical parameters and serum levels of IGF-I and IGFBP3.

\section{Materials and methods}

\section{Patients}

This study was performed in 27 ( 3 males, 24 females) chronic severe asthma patients who were treated at Dumlupinar University, Faculty of Medicine, Department of Chest Diseases, Kütahya, Turkey. The diagnosis of asthma was established on the ba- 


\section{1-694}

sis of the criteria proposed by 2014 Global Initiative for Asthma (GINA) Guideline (Global Initiative for Asthma Guideline, 2014). The control group consisted of 23 healthy age-gender matched (4 males, 19 females) subjects. All of the procedures and a written informed consent were obtained from each individual. The study protocol conforms to the ethical guidelines of Declaration of Helsinki, and was approved by the Ethics Committee of Afyon Kocatepe University.

Both groups were evaluated by several clinical parameters such as; asthma control test (ACT) puan, systolic and diastolic blood pressure, pulse, $\mathrm{O}_{2}$ saturation, FVC (Forced Vital Capacity) (ml, \%), FEV1 (Forced Expiratory Volume in 1 second) (ml, \%), FEV1/FVC, FEF2575 (Forced Expiratory Flow 25 second/75 second) (\%), PEF (Peak Expiratory Flow) (ml, \%). All individuals were assessed by the criteria according to the asthma control test to calculate ACT puan. For this purpose, the following questions were asked (in the past 4 weeks): 1) How much of the time did your asthma keep you from getting as much done at work, school or at home? 2) How often have you had shortness of breath? 3) How often did your asthma symptoms (wheezing, coughing, shortness of breath, chest tightness or pain) wake you up at night or earlier than usual in the morning? 4) How often have you used your rescue inhaler or nebulizer medication (such as albuterol)? 5) How would you rate your asthma control during the past 4 weeks? The patients scored these questions 1 to 5 . Asthma was grouped as well-controlled, partly controlled and uncontrolled according to the ACT puan; $=25,=20-24, \leq 19$; respectively (Nathan et al, 2004).

\section{ELISA analyses}

Peripheral blood samples were collected in tubes without EDTA from all subjects. After centrifugation, serum of each individual was stored at $-80{ }^{\circ} \mathrm{C}$ until ELISA analysis. Serum concentrations of IGF-I (Cusabio Biotech, Cat No CSB-E04580h) and IGFBP3 (Boster Human, Cat No EK0386) were analyzed by human ELISA assay kits. Chemiluminescence data were analyzed by an ELISA microplate reader (das, Digital and Analog Systems, Vimercate, MI, Italy).

\section{Statistical analyses}

Statistical analyses were performed by SPSS (Statistical Package for Social Sciences, Chicago, IL, USA) 16.0 package program. Serum levels of IGF-I, IGFBP3 and clinical parameters were given as mean \pm standard error of the mean (SEM). Statistical significances between the two groups were analyzed by Mann-Whitney $\mathrm{U}$ test. Differences were considered significant at $\mathrm{p}<0.05$. Pearson correlations were calculated to discern the relationship between clinical parameters and serum levels of proteins of interest.

\section{Results}

There were no statistically significant differences for pulse, FVC (ml, \%), FEV1 (ml, \%) and PEF (ml, \%) (Tab. 1).

ACT puan, $\mathrm{O}_{2}$ saturation, FEV1/FVC ratio and FEF2575 (\%) were significantly lower in the asthma group compared to the
Tab. 1. The comparisons of characteristics between the patient and control groups.

\begin{tabular}{lccc}
\hline & Asthma & Control & $\mathrm{p}$ \\
\hline IGF $-\mathrm{I}(\mathrm{ng} / \mathrm{ml})$ & $2.74 \pm 0.3$ & $0.85 \pm 0.3$ & $0.000^{* * *}$ \\
\hline IGFIBP3 $(\mathrm{pg} / \mathrm{ml})$ & $526.21 \pm 19.25$ & $459.31 \pm 40.90$ & $0.006^{* *}$ \\
\hline ACT puan & $14.68 \pm 0.1$ & $25.00 \pm 0.0$ & $0.000^{* * *}$ \\
\hline $\begin{array}{l}\text { Systolic Blood } \\
\text { Pressure (mmHg) }\end{array}$ & $115.93 \pm 2.71$ & $99.69 \pm 4.94$ & $0.001^{* * *}$ \\
\hline $\begin{array}{l}\text { Diastolic Blood } \\
\text { Pressure (mmHg) }\end{array}$ & $76.40 \pm 2.38$ & $68.91 \pm 2.72$ & $0.034^{*}$ \\
\hline Pulse & $85.68 \pm 2.29$ & $80.67 \pm 1.94$ & 0.086 \\
\hline O $_{2}$ Saturation & $97.65 \pm 0.41$ & $98.67 \pm 1.19$ & $0.035^{*}$ \\
\hline FVC (ml) & $2701.74 \pm 189.24$ & $3151.54 \pm 255.58$ & 0.172 \\
\hline FVC (\%) & $83.55 \pm 3.80$ & $85.15 \pm 4.61$ & 0.754 \\
\hline FEV1 (ml) & $2211.30 \pm 150.59$ & $2796.92 \pm 263.04$ & 0.084 \\
\hline FEV1 (\%) & $78.82 \pm 3.73$ & $89.85 \pm 4.97$ & 0.143 \\
\hline FEV1/FVC ratio (\%) & $77.64 \pm 1.96$ & $87.98 \pm 1.75$ & $0.002^{* * *}$ \\
\hline FEF2575 & $3240 \pm 360$ & $3333 \pm 464$ & 0.866 \\
\hline FEF2575(\%) & $54.89 \pm 6.67$ & $95.83 \pm 8.79$ & $0.004^{* * *}$ \\
\hline PEF (ml) & $3801.27 \pm 441.34$ & $4639.17 \pm 833.49$ & 0.387 \\
\hline PEF (\%) & $62.49 \pm 4.25$ & $76.75 \pm 5.77$ & 0.084 \\
\hline Da
\end{tabular}

Data are mean \pm SD. IGF-I; Insulin like growth factor I, IGFBP3; Insulin like growth binding protein, ACT puan; Asthma control test puan, FVC; forced vital capacity, FEV1; forced expiratory volume in 1 second, FEF2575; Forced Expiratory Flow 25 second/75 second, PEF; Peak Expiratory Flow. * $\mathrm{p}<0.05$ vs. control group (MannWhitney U Test), ${ }^{* *} \mathrm{p}<0.01$ vs. control group (Mann-Whitney U Test), ${ }^{* * *} \mathrm{p}<$ 0.005 vs. control group (Mann-Whitney U Test).

Tab. 2. Pearson correlations of evaluated parameters.

\begin{tabular}{lcccc}
\hline & IGF - I & $p$ & IGFBP3 & $p$ \\
\hline IGFBP3 & 0.442 & $0.001^{* * *}$ & 0.442 & $0.001^{* * *}$ \\
\hline ACT Puan & -0.505 & $0.001^{* * *}$ & -0.233 & 0.133 \\
\hline $\begin{array}{l}\text { Systolic Blood } \\
\text { Pressure (mmHg) }\end{array}$ & 0.270 & 0.058 & 0.363 & $0.010^{* *}$ \\
\hline $\begin{array}{l}\text { Diastolic Blood } \\
\text { Pressure (mmHg) }\end{array}$ & 0.208 & 0.147 & 0.275 & 0.053 \\
\hline Pulse & 0.080 & 0.667 & 0.111 & 0.552 \\
\hline $\mathrm{O}_{2}$ Saturation & -0.454 & $0.009^{* *}$ & -0.206 & 0.258 \\
\hline FVC (ml) & -0.193 & 0.260 & -0.326 & 0.052 \\
\hline FVC $(\%)$ & -0.044 & 0.799 & -0.200 & 0.242 \\
\hline FEV1 (ml) & -0.314 & 0.062 & -0.334 & $0.046^{*}$ \\
\hline FEV1 (\%) & -0.236 & 0.166 & -0.166 & 0.333 \\
\hline FEV1/FVC ratio (\%) & -0.414 & $0.012^{*}$ & -0.088 & 0.610 \\
\hline FEF2575 & 0.062 & 0.733 & -0.060 & 0.738 \\
\hline FEF2575(\%) & -0.448 & $0.010^{*}$ & -0.108 & 0.556 \\
\hline PEF (ml) & -0.122 & 0.492 & -0.093 & 0.602 \\
\hline PEF $(\%)$ & -0.245 & 0.162 & -0.096 & 0.587 \\
\hline IGF- $1 \%$
\end{tabular}

IGF-I; Insulin like growth factor I, IGFBP3; Insulin like growth binding protein, ACT puan; Asthma control test puan, FVC; forced vital capacity, FEV1; forced expiratory volume in 1 second, FEF2575; Forced Expiratory Flow 25 second/75 second, PEF; Peak Expiratory Flow. * $\mathrm{p}<0.05$ vs control group (Mann-Whitney U Test), ** $\mathrm{p}$ $<0.01$ vs. control group (Mann-Whitney U Test), ${ }^{* * *} \mathrm{p}<0.005$ vs. control group (Mann-Whitney U Test)

control group, respectively; $\mathrm{p}=0.000, \mathrm{p}=0.035, \mathrm{p}=0.002, \mathrm{p}=$ 0.004 (Tab. 1). Systolic and diastolic blood pressures were significantly higher in asthma group compared to the control group, respectively; $p=0.001, p=0.034$ (Tab. 1). Serum levels of IGF-I and IGFBP3 were significantly higher in the asthma group than 


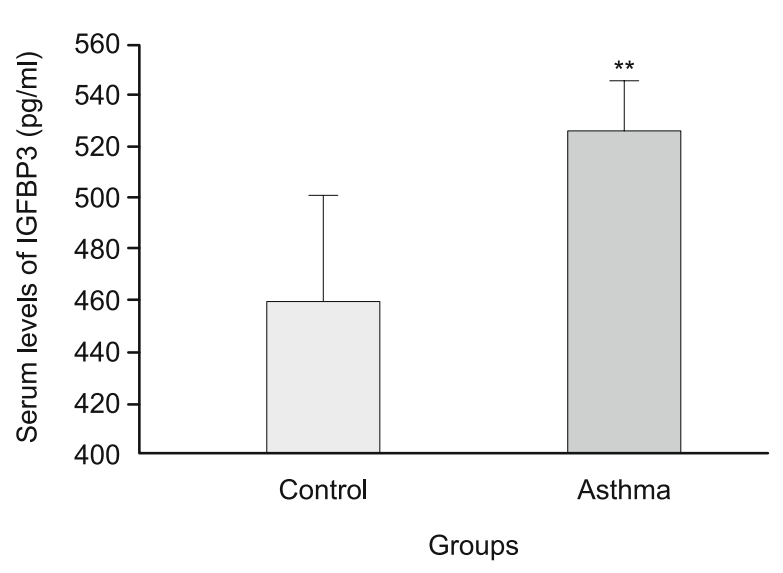

Fig. 1. Serum levels of IGF $-\mathbf{I}$ in asthma and control groups. $* * \mathbf{p}<$ 0.005 vs. control group (Mann-Whitney U Ttest). IGF-I; Insulin like growth factor I.

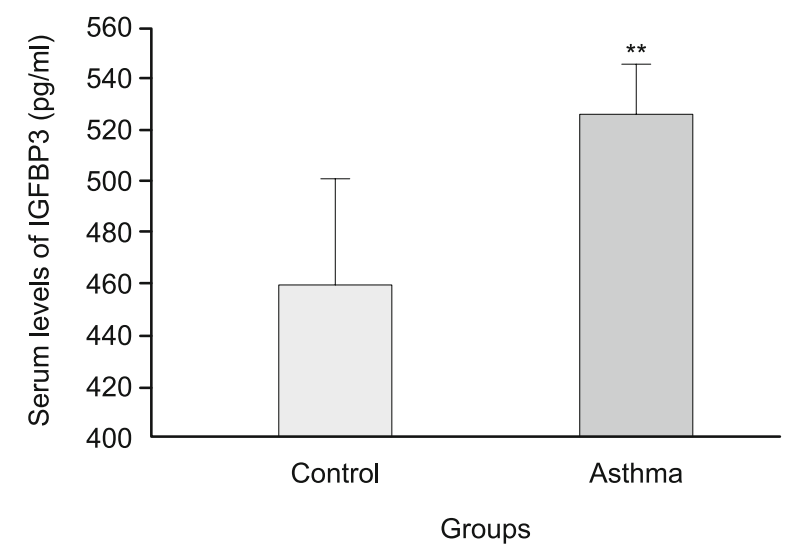

Fig. 2. Serum levels of IGFBP3 in asthma and control groups. ** p $<0.01$ vs. control group (Mann- Whitney U Ttest). IGFBP3; Insulin like growth factor binding protein 3 .

in the control group, respectively; $\mathrm{p}=0.000, \mathrm{p}=0.006$ (Tab. 1) (Figs 1 and 2).

Significantly negative correlation was found between the serum level of IGF-I and ACT puan, saturation, FEV1/FVC, $\%$ FEF2575; $\mathrm{p}=0.001, \mathrm{p}=0.009, \mathrm{p}=0.02, \mathrm{p}=0.01$; respectively (Tab. 2). Significantly positive correlation was found between the serum level of IGFBP3 and IGF-I, systolic blood pressure. Significantly negative correlation was found between the serum level of IGFBP3 and FEV1 (ml); $\mathrm{p}=0.001, \mathrm{p}=0.01, \mathrm{p}=0.046$; respectively (Tab. 2).

\section{Discussion}

IGF-I has been identified as one of the most important molecules in the pathogenesis of asthma in the manner of inducing fibrosis, airway inflammation and hyper-responsiveness and airway smooth muscle hyperplasia (Lee et al, 2014). IGF-I receptor (IGF-IR) has a high affinity for IGF-I and it mediates actions of IGF-I. Their complex induces pro-inflammatory responses (Lee et al, 2014, Siddle et al, 2001). IGFBP3 is binding more than $70 \%$ circulating IGF-I with higher affinity than IGF-IR. Therefore, IGFBP3 is mainly responsible for inhibition of IGF-I actions by reducing IGF-I/ IGF-IR pathway (Jones et al, 1995). On the other hand, it can reserve IGF-I to protect down regulation of IGF-I receptor. That is why it is speculated that IGFBP3 has dual effect on IGF-I action which means high level of IGFBP3 reduces the action of IGF-I and low level of IGFBP3 enhances the action of IGF-I (Conover et al, 1991, Wetterau et al, 1999).

Current strategies for asthma treatment can be inadequate approximately for $10 \%$ patients with asthma. Additionally, they are mostly not curing asthma because they have weak effect on inhibiting airway remodeling (Lee et al, 2014). That is why new treatments are needed for effective asthma treatment. IGF-I and IGFBP3 are possible targets for asthma treatment strategies because of their role in the pathogenesis of asthma. It has been shown that mRNA levels of IGF-I in endobronchial biopsies are significantly higher in asthmatic patients than controls. This elevation was found to be correlated with subepithelial fibrosis (Hoshino et al, 1998). In the literature, we could not recognize any studies that are comparing serum levels of IGF-I between asthmatic patients and healthy individuals. In the present study, serum levels of IGF-I was found significantly higher in asthma group than in the control group. If we consider that this elevation is in significantly negative correlation with ACT puan, $\mathrm{O}_{2}$ saturation, FEV1/ FVC and \%FEF2575, we suppose that IGF-I may be involved the pathogenesis of asthma.

IGFBP3 has been found in high levels in tissues and bronchial lavage fluids of asthmatic patients. That is why it is suggested that there is a possible interaction with IGFBP3 and asthma (Veraldi et al, 2009). IGFBP3 takes a role in the pathophysiology of asthma dependent from IGF-I as well as independent from IGF-I. Thus, it is suggested that up-regulation of IGFBP3 can be one of the new strategies in treatment of asthma (Lee et al, 2014). We have found that serum level of IGFBP3 in asthma group was significantly higher than in control. It is known that circulating level of IGFBP3 is elevated by IGF-I and glucocorticosteroids (DiGirolamo et al, 2007, Conover et al, 1995). Our results also indicate that serum levels of IGF-I and IGFBP3 are significantly positively correlated with each other. That can be one of the reasons for elevated level of IGFBP3. Additionally, it can be a result of glucocorticosteroid treatment. We did not examine serum levels of IGF-I and IGFBP3 before and after treatment. That is why we can not exactly conclude the reason for the elevation of IGFBP3 in asthmatic patients. Serum level of IGFBP3 is significantly positively correlated with systolic blood pressure. It has been speculated that IGFBP3 has proatherogenic effect (Colangelo et al, 2004). We assume that this effect of IGFBP3 may lead to an increase in systolic blood pressure which can cause the development of comorbidities in asthmatic patients.

\section{Conclusions}

Current treatment strategies of asthma do not suppress the production of IGF-I which plays an important role in the pathophysiology of asthma. On the other hand, same treatments cause 
691-694

elevated serum level of IGFBP3 which is more likely to reduce IGF-I action. Moreover elevated serum level of IGFBP3 can cause high systolic blood pressure. We think that this point should be kept in mind during the review of treatment strategies for asthma.

\section{References}

1. Spiess J, Rivier J, Vale W. Characterization of rat hypothalamic growth hormone-releasing factor. Nature 1983; 303: 532-535.

2. Kojima M, Hosoda H, Date Y, Nakazato M, Matsuo H, Kangawa K. Ghrelin is a growth-hormone-releasing acylated peptide from stomach. Nature 1999; 402: 656-660.

3. Butler AA, Le Roith D. Control of growth by the somatropic axis: growth hormone and the insulin-like growth factors have related and independent roles. Annu Rev Physiol 2001; 63: 141-164.

4. Brazeau P, Vale W, Burgus R, Ling N, Butcher M, Rivier J et al. Hypothalamic polypeptide that inhibits the secretion of immunoreactive pituitary growth hormone. Science 1973; 179: 77-79.

5. Lee H, Kim SR, Oh Y, Cho SH, Schleimer RP, Lee YC. Targeting insulin-like growth factor-I and insulin-like growth factor-binding protein-3 signaling pathways. A novel therapeutic approach for asthma. Am J Respir Cell Mol Biol 2014; 50: 667-677.

6. Jogie-Brahim S, Feldman D, Oh Y. Unraveling insulin-like growth factor binding protein-3 actions in human disease. Endocr Rev 2009; 30 : 417-437.

7. Domené HM, Bengolea SV, Jasper HG, Boisclair YR. Acid-labile subunit deficiency: phenotypic similarities and differences between human and mouse. J Endocrinol Invest 2005; 28: 43-46.

8. Yaren A, Turgut S, Ayada C, Akcilar R, Degirmencioglu S, Gokoz Dogu G. Insulin-like growth factor I (Igf-1) gene polymorphism in patients with non-metastatic breast cancer. Gene 2012; 503: 244-247.

9. Barnes PJ. The role of inflammation and anti-inflammatory medication in asthma. Respir Med 2002; 96: 9-15.

10. Bousquet J, Jeffery PK, Busse WW, Johnson M, Vignola AM. Asthma. From bronchoconstriction to airways inflammation and remodeling. Am J Respir Crit Care Med 2000; 161: 1720-1745.
11. Roche WR, Beasley R, Williams JH, Holgate ST. Subepithelial fibrosis in the bronchi of asthmatics. Lancet 1989; 1: 520-524.

12. Global Initiative for Asthma Guideline 2014. Available from: http: //www.ginasthma.org/local/uploads/files/GINA_Pocket_2014_Jun11.pdf

13. Nathan RA, Sorkness CA, Kosinski M, Schatz M, Li JT, Marcus P et al. Development of the asthma control test: A survey for assessing asthma control. J Allergy Clin Immunol 2004; 113: 59-65.

14. Siddle K, Ursø B, Niesler CA, Cope DL, Molina L, Surinya KH et al. Specificity in ligand binding and intracellular signalling by insulin and insulin-like growth factor receptors. Biochem Soc Trans 2001; 29: 513-525.

15. Jones J, Clemmons DR. Insulin-like growth factors and their binding proteins: biological actions. Endocr Rev 1995; 16: 3-34.

16. Conover CA, Powell DR. Insulin-like growth factor (IGF)-binding protein-3 blocks IGF-I--induced receptor down-regulation and cell desensitization in cultured bovine fibroblasts. Endocrinology 1991; 129: 710-716.

17. Wetterau LA, Moore MG, Lee KW, Shim ML, Cohen P. Novel aspects of the insulin-like growth factor binding proteins. Mol Genet Metab 1999; 68: 161-181.

18. Hoshino M, Nakamura Y, Sim JJ, Yamashiro Y, Uchida K, Hosaka $\mathrm{K}$ et al. Inhaled corticosteroid reduced lamina reticularis of the basement membrane by modulation of insulin-like growth factor (IGF)-I expression in bronchial asthma. Clin Exp Allergy 1998; 28: 568-577.

19. Veraldi KL, Gibson BT, Yasuoka H, Myerburg MM, Kelly EA, Balzar S et al. Role of insulin-like growth factor binding protein-3 in allergic airway remodeling. Am J Respir Crit Care Med 2009; 180: 611-617.

20. DiGirolamo DJ, Mukherjee A, Fulzele K, Gan Y, Cao X, Frank SJ et al. Mode of growth hormone action in osteoblasts. J Biol Chem 2007; 282: 31666-31674.

21. Conover CA, Clarkson JT, Bale LK. Effect of glucocorticoid on insulin - like growth factor (IGF) regulation of IGF-binding protein expression in fibroblasts. Endocrinology 1995; 136: 1403-1410.

22. Colangelo LA, Liu K, Gapstur SM; CARDIA Male Hormone Study. Insulin-like growth factor-1, insulin-like growth factor binding protein-3, and cardiovascular disease risk factors in young black men and white men: the CARDIA Male Hormone Study. Am J Epidemiol 2004; 160: 750-757.

Received June 13, 2017. Accepted July 18, 2017. 